УДК 378.016:796.011.

DOI https://doi.org/10.26661/2522-4360-2021-2-38

\title{
АКМЕОЛОГІЧНІ СКЛАДНИКИ РОЗВИТКУ РУХОВИХ ЯКОСТЕЙ ЗДОБУВАЧІВ ВИЩОЇ ОСВІТИ
}

\author{
Самохвалова І. Ю. \\ старший викладач кафедри фізичного виховання \\ Сумський начіональний аграрний університет \\ вул. Герасима Кондратьєва, 160, Суми, Украӥна \\ orcid.org/0000-0001-7017-6915 \\ irasport2015@ukr.net \\ Харченко С. М. \\ кандидат педагогічних наук, \\ дочент кафедри фізичного виховання \\ Сумський національний аграрний університет \\ вул. Герасима Кондратьєва, 160, Суми, Украӥна \\ orcid.org/0000-0002-4975-321X \\ kharchenko-inna@ukr.net
}

\begin{abstract}
Ключові слова: акмезасади, професійна спрямованість, самореалізачія, експертне оиінювання, фізичне виховання.
\end{abstract}

Стаття присвячена проблемі пошуку методів та засобів розвитку рухових якостей, які допоможуть здобувачам вищої освіти в самореалізації та прагненні до свого «акме».

Доведено, що на розвиток рухових якостей студентів значною мірою впливає спрямованість майбутньої професійної діяльності, яка визначає особливості фізичної працездатності, рухової активності та необхідний рівень фізичного здоров'я майбутніх фахівців.

Мета дослідження: визначення та обгрунтування акмеологічних засад розвитку рухових якостей студентів закладів вищої освіти в умовах професійної підготовки.

У дослідженні використовувалися такі методи: аналіз науковометодичної літератури, анкетування, метод експертного опитування, метод математичної статистики.

Визначення акмеологічних засад розвитку рухових якостей студентів закладів вищої освіти відбувалося методом експертних оцінок. Обрано шість експертів, які мають досвід роботи зі студентами закладів вищої освіти різних профілів не менше 5 років та рівень кваліфікації спеціаліст/ магістр фізичної культури і спорту. Експертам пропонувалося оцінити за п’ятибальною системою окремо кожну з наданих аксмезасад та шляхи їх упровадження, які необхідно враховувати для розвитку рухових якостей студентів у процесі професійної підготовки.

Для обробки результатів використовувалися методи ранжування та конкордації Кендалла. У результаті були отримані відповідні бали, а потім виведена загальна рейтингова оцінка акмезасад, вибрані ті, в яких оцінка перевищувало індекс 0,75 бала.

Визначено шість акмезасад розвитку рухових якостей студентів закладів вищої освіти: ціннісне ставлення до здоров'я; формування здорового способу життя; умови для фізичного розвитку відповідно до професійної спрямованості; умови для духовного та соціального розвитку; самоосвіта; фізичне самовдосконалення.

У результаті дослідження установлено залежність між акмезасадами, шляхами та умовами формування рухових якостей, що визначає оптимальний їх розвиток у студентів закладів вищої освіти в умовах професійної підготовки. 


\title{
DETERMINATION OF ACMEOLOGICAL FOUNDATION OF STUDENTS'MOTOR SKILLS DEVELOPMENT
}

\author{
Samokhvalova I. Yu. \\ Lecturer at the Department of Physical Education \\ Sumy National Agrarian University \\ Gerasim Kondratiev str., 160, Sumy, Ukraine \\ orcid.org/0000-0001-7017-6915 \\ irasport2015@ukr.net \\ Kharchenko S. M. \\ Candidate of Pedagogical Sciences, \\ Associate Professor at the Department of Physical Education \\ Sumy National Agrarian University \\ Gerasim Kondratiev str., 160, Sumy, Ukraine \\ orcid.org/0000-0002-4975-321X \\ kharchenko-inna@ukr.net
}

Key words: acme foundations, professional orientation, self-realization, expert evaluation, physical education.
The article is devoted to the problem of finding methods and means of physical education that will help applicants for higher education in self-realization and the pursuit of their "acme".

Maintaining health at the optimal possible level and a good physical condition is a prerequisite for the completeness of personal manifestations and high achievements of man in his professional activities.

The purpose of the study is to determine and substantiate the acmeological foundations of motor skills development in students of higher education institutions in terms of training.

The following methods were used in the research: analysis of scientificmethodological literature, questionnaire, method of expert evaluation, method of mathematical statistics.

Determination of acmeological foundations of motor skills development in students of higher education institutions was carried out by the method of expert evaluation. For this purpose, six experts were selected who had experience of working with students of higher education institutions of various profiles for at least 5 years and the level of qualification of a specialist/master of physical culture and sports. The experts were asked to evaluate on a fivepoint scale separately each of the provided acme foundations and ways of their implementation, which must be taken into account for the students' motor skills development in the process of professional training.

Kendall's ranking and concordance methods were used to process the results. As a result, the corresponding scores were obtained, and then the overall rating score of acme foundations was derived and were selected those in which the score exceeded the index by 0.75 points.

According to the results of the expert evaluation, six principles of students' motor skills development in higher education institutions were determined: value attitude to health; formation of a healthy lifestyle; conditions for physical development in accordance with professional orientation; conditions for spiritual and social development; self-education; physical self-improvement.

The study identified the relationship between acme foundations, ways and conditions of motor skills development, which determines their optimal development in students of the higher education institutions in terms of training. 
Постановка проблеми. В умовах інформатизації усіх сфер суспільства змінюється сутність і значення освіти, зростає актуальність забезпечення здоров'я людини як суспільної цінності, вагомого значення набуває особистісний розвиток людини, iii вмотивованість у досягненні власного професійного «акме» $[5 ; 6]$.

Одним 3 основних завдань освітнього процесу з фізичного виховання закладу вищої освіти $\epsilon$ пошук найбільш ефективних шляхів розкриття потенційних можливостей, розвитку необхідних рухових якостей за допомогою різних видів діяльності для підвищення особистісної та професійної культури студентів [4].

На розвиток рухових якостей студентів значною мірою впливає спрямованість майбутньої професійної діяльності, яка визначає особливості фізичної працездатності, рухової активності та необхідний рівень фізичного здоров'я майбутніх фахівців.

Дослідники виділяють такі фактори впливу на рухові якості студентів закладів вищої освіти в умовах професійної підготовки, як: ціннісне ставлення до здоров'я та достатньої фізичної підготовленості; специфіка майбутньої професійної діяльності і професійної підготовки; особливості фізичної працездатності, професійної рухової активності та необхідний рівень фізичного здоров'я майбутніх фахівців; професійні та особистісні акме, які виражаються у мотивації до рухової діяльності та психологічних станах здобувачів вищої освіти у процесі розвитку і вдосконалення рухових якостей $[1 ; 2 ; 6]$.

Науковці шукають методи та засоби, які допоможуть студентам у прагненні досягти вершин професіоналізму. І.В. Іваній зауважує, що акмеологічний підхід дає змогу під час навчання не лише скеровувати здобувача освіти на опанування компетенцій, але й спрямувати його до вершин професійної діяльності [3].

У роботах О.В. Зеленюк, В.В. Чекмарьової зазначається, що соціальний статус людини реалізується через біологічну складову частину, тобто з'являється можливість «визначити ефективність прикладного напряму акмеології - педагогічної акмеології фізичного виховання як спеціалізованої культурної практики, пов'язаної із процесом удосконалення студентом власного тіла, а відтак і покращення стану здоров'я» [4, с. 36].

В умовах погіршення стану здоров'я населення України та набуття дисципліною «Фізичне виховання» статусу вибіркового факультативного курсу для ефективного розвитку рухових якостей студентів закладів вищої освіти важливим $є$ акмеологічний підхід.

На сучасному етапі арсенал методичних і наукових розробокізпроблеми розвитку рухових якостей студентів на акмеологічних засадах $є$ недостатнім і потребує більш глибокого дослідження.

Мета дослідження - визначення та обгрунтування акмеологічних засад розвитку рухових якостей студентів закладів вищої освіти в умовах професійної підготовки.

Завдання дослідження:

1. Аналіз науково-методичної літератури $з$ цієї проблеми.

2. Визначення акмеологічних аспектів розвитку рухових якостей студентів закладів вищої освіти в умовах професійної підготовки.

3. Встановлення залежностей між акмеологічними засадами, умовами їх формування та шляхами розвитку рухових якостей студентів.

Виклад основного матеріалу дослідження. Для вивчення акмеологічної обізнаності викладачів фізичного виховання закладів вищої освіти нами була розроблена анкета. У дослідженні брали участь викладачі фізичного виховання Сумського національного аграрного університету та Сумського державного педагогічного університету імені А.С. Макаренка.

Акмеологічний підхід у царині фізичної культури людини - це вдосконалення іiі тіла, моральності і вольових якостей, що включає сукупність принципів, прийомів і методів, які забезпечують активний саморозвиток і самореалізацію [5].

За даними анкетування встановлено, що значна частина опитаних викладачів $(56,8 \%)$ можуть дати визначення понять «самоосвіта», «самовиховання», «саморозвиток». Але майже половина респондентів $(46,9 \%)$ не усвідомлюють важливості самостійної роботи, витрачаючи на неї лише одну годину на добу. Серед опитаних $45,6 \%$ викладачів не приділяють уваги фаховій науковій та навчально-методичній літературі та не беруть участі у науково-дослідних проектах (52,9\%), що передбачає сформовану здатність до самоосвіти, самовиховання та саморозвитку. Це свідчить про те, що більшість викладачів недостатньо усвідомлюють важливість оволодіння акмеологічною компетентністю та недостатньо вмотивовані щодо професійного розвитку.

У контексті дослідження цікаво було дізнатися, як респонденти розуміють дефініції «акмеологія», «акмеологічні засади», чи володіють викладачі фізичного виховання знаннями щодо закономірностей, умов, факторів та стимулів самореалізації рухового потенціалу студентів як важливого чинника досягнення ними вершин професіоналізму.

Результати опитування свідчать, що викладачі фізичного виховання сумських закладів вищої освіти не повною мірою розуміють поняття «акмеологія» і можуть дати його визначення. Так, 16,2\% респондентів вважають, що «акмеологія» - це нова ідея; 10,5\% викладачів припускають, 
що це реорганізація, створення нового; 5,4\% респондентів визначають акмеологію як новий зміст навчального процесу; 5,4\% - як інноваційний підхід у професійній діяльності.

Щодо володіння викладачами інформацією про сучасні акметехнології, результати анкетування показали, що 82,4\% опитаних не знають форм та методів акмеологічного навчання, не мають інформації щодо сучасних акмеотехнологій; 17,6\% респондентів частково мають уявлення про акмеспрямоване навчання.

Таким чином, проведене опитування підтверджує необхідність розроблення й обгрунтування акмеологічних засад розвитку рухових якостей студентів закладів вищої освіти в умовах професійної діяльності.

Проаналізувавши дослідження Т.Г. Дереки [1], ми виділили такі акмеологічні засади розвитку рухових якостей студентів закладів вищої освіти, як:

- усвідомлення найближчих і кінцевих цілей фізичного виховання;

- усвідомлення теоретичного та практичного значення засвоюваних знань та вмінь;

- показ «перспективних ліній» у розвитку особистості;

- професійна спрямованість діяльності;

- вибір завдань, що створюють проблемні ситуації у структурі навчальної діяльності;

- наявність життєлюбності та «пізнавального психологічного клімату» в групі;

- прояв активності особистості у процесі професійного становлення;

- забезпечення можливості саморозвитку, самовдосконалення, досягнення особистісного й професійного акме;

- зміст фізичного виховання на засадах акмеології має реалізуватися різними формами: навчальні заняття (лекції, семінари, практичні та/ або лабораторні заняття, консультаціі), самостійна та науково-дослідна робота студентів, практична підготовка та контрольні заходи;

- практичне застосування засвоєних теоретичних знань через індивідуальне виконання завдань на практичних заняттях;

- формування практичних умінь і навичок, необхідних у майбутній професійній діяльності;

- розвиток самостійності;

- індивідуалізація завдань (аудиторних та позааудиторних) та постійне їх оновлення;

- творча особистість викладача, який покликаний допомогти студенту розкрити свій творчий потенціал, визначити перспективи свого внутрішнього зростання;

- урахування спеціалізації та професійної спрямованості.

Визначення акмеологічних засад розвитку рухових якостей студентів закладів вищої освіти в умовах професійної підготовки відбувалось із застосуванням методу експертних оцінок. Для цього було обрано шість експертів, які мають досвід роботи зі студентами закладів вищої освіти різних профілів не менше 5 років та рівень кваліфікації спеціаліст/магістр фізичної культури i спорту. Експертам пропонувався оцінити за п'ятибальною системою окремо кожну з аксмезасад (перелік наведений вище) та шляхів їх упровадження, які необхідно враховувати для розвитку рухових якостей студентів у процесі професійної підготовки. Для обробки результатів використовувалися методи ранжування та конкордації Кендалла. У результаті були отримані відповідні бали, а потім виведена загальна рейтингова оцінка акмезасад, вибрані ті, в яких оцінка перевищувало індекс 0,75 бала.

За результатами експертного оцінювання було визначено шість акмезасад розвитку рухових якостей студентів закладів вищої освіти: ціннісне ставлення до здоров'я; формування здорового способу життя; умови для фізичного розвитку відповідно до професійної спрямованості; умови для духовного та соціального розвитку; самоосвіта; фізичне самовдосконалення.

У результаті аналізу науково-методичної літератури було виділено шляхи врахування визначених акмезасад під час розвитку рухових якостей студентів: виконання різних видів фізичних вправ залежно від професійної спрямованості; рухова активність у позанавчальний час; покращення емоційного фону; формування особистісних якостей; управління процесом власного здоров'язбереження (мотивація здорового способу життя).

Зазначимо, що у процесі розвитку рухових якостей студентів закладів вищої освіти важливими також $є$ умови їх формування, серед яких: вік; спадковість; соціальні умови та напрям обраної професії; організація фізичного виховання залежно від стану здоров'я та типологічних особливостей; руховий досвід, рухова активність та спортивні досягнення.

Згідно з акмеологічним підходом, у прагненні до фізичної досконалості, розвитку рухових якостей проявляється самоствердження особистості, здатність до досягнення цілей [5].

Ми встановили залежність між акмезасадами, шляхами їх упровадження та умовами розвитку рухових якостей (таблиця 1).

Висновки. У результаті проведеного експертного оцінювання було визначено основні акмезасади розвитку рухових якостей студентів закладів вищої освіти: ціннісне ставлення до здоров'я; формування здорового способу життя; умови для фізичного розвитку відповідно до професійної спрямованості; умови для духовного та соціального розвитку; самоосвіта; фізичне 
Таблиця 1

Залежність між акмезасадами розвитку рухових якостей студентів, шляхами їх упровадження та умовами розвитку

\begin{tabular}{|c|c|c|}
\hline Акмезасади & Шляхи врахування акме & Умови розвитку рухових якостей \\
\hline \multirow[t]{3}{*}{$\begin{array}{l}\text { Ціннісне ставлення до } \\
\text { здоров'я }\end{array}$} & $\begin{array}{l}\text { Застосування різних видів фізичних } \\
\text { вправ залежно від професійної } \\
\text { спрямованості }\end{array}$ & \multirow{3}{*}{$\begin{array}{l}\text { - організація фізичного виховання } \\
\text { залежно від стану здоров'я та } \\
\text { типологічних особливостей; } \\
\text { - руховий досвід, рухова активність } \\
\text { та спортивні досягнення. }\end{array}$} \\
\hline & Формування особистісних якостей & \\
\hline & $\begin{array}{l}\text { Управління процесом власного } \\
\text { здоров'язбереження (мотивація здорового } \\
\text { способу життя) }\end{array}$ & \\
\hline \multirow{2}{*}{$\begin{array}{l}\text { Формування здорового } \\
\text { способу життя }\end{array}$} & Рухова активність у позанавчальний час & \multirow{2}{*}{$\begin{array}{l}\text { - соціальні умови та напрям обраної } \\
\text { професії; } \\
\text { - руховий досвід, рухова активність } \\
\text { та спортивні досягнення. }\end{array}$} \\
\hline & $\begin{array}{l}\text { Управління процесом власного } \\
\text { здоров'язбереження (мотивація здорового } \\
\text { способу життя) }\end{array}$ & \\
\hline \multirow[t]{2}{*}{$\begin{array}{l}\text { Умови для фізичного } \\
\text { розвитку відповідно до } \\
\text { професійної спрямованості }\end{array}$} & $\begin{array}{l}\text { Застосування різних видів фізичних } \\
\text { вправ залежно від професійної } \\
\text { спрямованості }\end{array}$ & \multirow[t]{2}{*}{$\begin{array}{l}\text { - соціальні умови та напрям обраної } \\
\text { професії. }\end{array}$} \\
\hline & Покращення емоційного фону & \\
\hline \multirow[t]{2}{*}{$\begin{array}{l}\text { Умови для духовного та } \\
\text { соціального розвитку }\end{array}$} & Формування особистісних якостей & \multirow{2}{*}{$\begin{array}{l}\text { - соціальні умови та напрям обраної } \\
\text { професії; } \\
\text { - організація фізичного виховання } \\
\text { залежно від стану здоров'я та } \\
\text { типологічних особливостей; } \\
\text { - руховий досвід, рухова активність } \\
\text { та спортивні досягнення }\end{array}$} \\
\hline & Покращення емоційного фону & \\
\hline \multirow[t]{2}{*}{ Самоосвіта } & Покращення емоційного фону & \multirow{2}{*}{$\begin{array}{l}\text { - соціальні умови та напрям обраної } \\
\text { професії; } \\
\text { - організація фізичного виховання } \\
\text { залежно від стану здоров'я та } \\
\text { типологічних особливостей; } \\
\text { - руховий досвід, рухова активність } \\
\text { та спортивні досягнення } \\
\end{array}$} \\
\hline & $\begin{array}{l}\text { Управління процесом власного } \\
\text { здоров'язбереження (мотивація здорового } \\
\text { способу життя) }\end{array}$ & \\
\hline \multirow[t]{2}{*}{ Фізичне самовдосконалення } & Рухова активність у позанавчальний час & \multirow{2}{*}{$\begin{array}{l}\text { - руховий досвід, рухова активність } \\
\text { та спортивні досягнення }\end{array}$} \\
\hline & $\begin{array}{l}\text { Управління процесом власного } \\
\text { здоров'язбереження (мотивація здорового } \\
\text { способу життя) }\end{array}$ & \\
\hline
\end{tabular}

самовдосконалення. Встановлено залежності між визначеними акмезасадами, шляхами їх впровадження та умовами розвитку рухових якостей сту- дентів, за допомогою яких можна створити оптимальні умови для розвитку професійно важливих фізичних якостей.

\section{ЛІТЕРАТУРА}

1. Дерека Т.Г. Концептуальні засади акмеологічної спрямованої неперервної професійної підготовки фахівців фізичного виховання. Сучасні акмеологічні дослідження: теоретико - методологічні та прикладні аспекти:моногр.редкол.: В.О. Огнев’юк, С.О. Сисоєва, Я.С. Фруктова.К.: Київськ.ун- т імені Б. Гринченка, 2016. С. 639-663.

2. Дмитриев С.В. Акмеологические аспекты развития студента в образовательных технологиях. Bicник Чернігівського націінального педагогічного університету. Чернігів, 2012. Вип. 98. Т. 2. С. 5-8.

3. Іваній І.В. Культуролого - акмеологічний підхід до організації підготовки магістрів фізкультурних спеціальностей. Освітологічний дискус, 2017. № 1 - 2 (16 - 17). С. 38-51.

4. Зеленюк О.В. Чекмароьва В.В. Фізичне виховання студентської молоді у контексті сучасної педагогічної парадигми. Матеріали Міжнародної науково - практичної конференції «Фізична кільтура і спорт у сучасному суспільстві:досвід, проблеми, рішення». Київ, 2015. С. 33-38. 
5. Масалова О.Ю. Методологические подходы к формированию физической культуры студента в высшей школе. Вестник Адыгейского государственного университета. Серия 3: Педагогика и психология, 2012. № 3 (103). С. 170-180.

6. Сотська Г. Акмеологічний підхід у педагогічній освіті України. URL: https:/lib.iitta.gov.ua/ 709238/1/\%D1\%81\%D0\%BE\%D1\%82\%D1\%81\%D1\%8C\%D0\%BA\%D0\%B02.pdf

\section{REFERENCES}

1. Dereka T.G. (2016) Kontseptual'ni zasady akmeolohichnoyi spryamovanoyi neperervnoyi profesiynoyi pidhotovky fakhivtsiv fizychnoho vykhovannya. [Conceptual principles of acmeological directed continuous professional training of physical education specialists]. Modern acmeological research: theoretical-methodological and applied. P. 639-663.

2. Dmitriev S.V. (2012) Akmeolohycheskye aspekty razvytyya studenta v obrazovatel'nykh tekhnolohyyakh. [Acmeological aspects of student development in educational technologies]. Bulletin of Chernihiv National Pedagogical University. Vol. 2. P. 5-8.

3. Ivaniy I.V. (2017) Kul'turoloho - akmeolohichnyy pidkhid do orhanizatsiyi pidhotovky mahistriv fizkul'turnykh spetsial'nostey. [Culturologist - acmeological approach to the organization of training of masters of physical culture specialties]. Educational Discussion. Vol. 1 - 2 (16 - 17) P. 38-51.

4. Zelenyuk O.V., Chekmarova V.V. (2015) Fizychne vykhovannya student·s'koyi molodi u konteksti suchasnoyi pedahohichnoyi paradyhmy. [Physical education of student youth in the context of modern pedagogical paradigm]. Proceedings of the International scientific-practical conference "Physical culture and sports in modern society: experience, problems, solutions". P. 33-38.

5. Masalova O.Y. (2012) Metodolohycheskye podkhody k formyrovanyyu fyzycheskoy kul'tury studenta $\mathrm{v}$ vysshey shkole. [Methodological approaches to the formation of physical culture of students in higher education]. Bulletin of Adygea State University. № 3 (103). P. 170-180.

6. Sotska G. Akmeolohichnyy pidkhid u pedahohichniy osviti Ukrayiny [Acmeological approach in pedagogical education of Ukraine]. URL https://lib.iitta.gov.ua/709238/1/\%D1\%81\%D0\%BE\%D1\%82\% D1\%81\%D1\%8C\%D0 \% BA\% D0\% B02.pdf 